\title{
Studies on the transmissibility and etiology of orocutaneous tumors of brown bullheads Ictalurus nebulosus
}

\author{
Frederique M. Poulet ${ }^{1}$, James W. Casey ${ }^{2}$, Jan M. Spitsbergen ${ }^{1}$
} ${ }^{1}$ Department of Avian and Aquatic Animal Medicine, and ${ }^{2}$ Department of Microbiology, Immunology and Parasitology,
New York State College of Veterinary Medicine, Cornell University, Ithaca, New York 14853, USA

\begin{abstract}
To determine the transmissibility of orocutaneous neoplasms of brown bullheads Ictalurus nebulosus under laboratory conditions, 120 test fish were inoculated with cell-free filtered tumor homogenate or with live neoplastic cells prepared from pooled neoplasms collected from adult fish in the spring. Controls received vehicle alone or cells from a homologous cell line (BB). Inoculated fish were kept at 10,15 , and $20^{\circ} \mathrm{C}$. The disease was not transmitted in this 9 mo trial. Electron microscopic examination of the 2 inocula did not reveal viral particles. No cytopathic effects were observed in primary cultures of neoplastic cells or in BB monolayers inoculated with material derived from the neoplasms. Neither a mixed bovine papillomavirus and cottontail rabbit papillomavirus DNA probe (BPV-CRPV) nor a fish retrovirus probe (WDSV) recognized any homologous sequences on Southern blots of brown bullhead neoplasms. However, RNA-dependent DNA polymerase activity, presumably reverse transcriptase, absent from normal brown bullhead skin, was detected in neoplastic tissue and preferred $\mathrm{Mn}^{2+}$ as the divalent cation. Results suggest that the etiology of orocutaneous neoplasms of brown bullheads is probably multifactorial and integrated into the broad scheme of multistep carcinogenesis.
\end{abstract}

\section{INTRODUCTION}

The most frequent neoplasm reported in many different saltwater and freshwater fish species is the cutaneous and oral papilloma (Lucké \& Schlumberger 1941, Anders 1989, Ferguson 1989). Epizootics of orocutaneous tumors (papillomas and carcinomas) have been reported in brown bullheads Ictalurus nebulosus from both pristine waters and polluted sites throughout North America (Lucké \& Schlumberger 1941. Baumann et al. 1987, Smith et al. 1989, Bowser et al. 1991). The biologic and histopathologic characteristics of these orocutaneous papillomas and carcinomas have recently been described (Poulet et al. in press). The lesion progresses apparently from papilloma to carcinoma, and may in rare instances form neoplastic emboli (Lucké \& Schlumberger 1941, Smith et al. 1989). The etiology of these orocutaneous neoplasms in brown bullheads is unknown. Intracytoplasmic viruslike particles, tentatively identified as papillomaviruses, were detected within neoplastic epithelial cells (Edwards \& Samsonoff 1977), but this finding, not confirmed by other investigators (Bowser et al. 1991), remains controversial. In numerous mammalian species, some mucosal and epidermal papillomas, carcinomas, and fibropapillomas are induced by papillomaviruses (Fenner et al. 1987, Moulton 1990). In fish species, 2 herpesviruses were etiologically associated with epidermal neoplasms of salmonids [Salmonid Herpesvirus 3 or Oncorhynchus masou virus (OMV) (Kimura et al. 1981a, b, Yoshimizu et al. 1987), and Salmonid Herpesvirus 4 or Yamame tumor virus (Sano et al. 1983)]. A third herpesvirus, Cyprinid Herpesvirus 1 (Sano et al. 1985), is the causative agent of carp pox in the common carp. In addition, abundant reports describe the isolation or the electron microscopic detec- 
tion of herpesviruses, adenoviruses, rhabdoviruses, or retrovirus-like particles within hyperplastic or neoplastic lesions in various fish species (Ahne \& Kurstak 1989. Ferguson 1989). Previous experiments have demonstrated the transplantability of the brown bullhead orocutaneous tumors (Lucké \& Schlumberger 1941). Although in one case excessive water chlorination was implicated in epidermal papillomas of black bullheads Ictalurus melas (Grizzle et al. 1981, 1984), and in another case experimental induction of papillomas was achieved by painting organic extracts of river sediments rich in polycyclic aromatic hydrocarbons onto brown bullhead skin (Black 1983, 1988), attempts to correlate these neoplasms in a wild population of brown bullheads with chemical contaminants in situ have not been conclusive (Bowser et al. 1991). The species specificity (Bowser et al. 1991), the occurrence of the epizootics in unrelated fish populations inhabiting various geographic locations (Lucké \& Schlumberger 1941, Baumann et al. 1987, Smith et al. 1989, Harshbarger \& Clark 1990, Bowser et al. 1991), and a putative seasonal influence suggest an infectious etiology (Bowser et al. 1991). This paper reports the results of a 9 mo transmissibility trial of the neoplasm in healthy brown bullheads, and tests the hypothesis of a viral etiology by preliminary virus propagation attempts and DNA studies.

\section{MATERIALS AND METHODS}

Transmissibility trial. Two hundred and forty healthy brown bullheads, approximately $10 \mathrm{~cm}$ long, were collected with trap nets from a private pond, in which bullheads had been observed for over 6 yr with no history of orocutaneous tumors, in Marathon, New York, USA. One hundred and fifty additional brown bullheads were checked macroscopically for neoplasms. Four treatment groups of 20 fish were placed into 40 l aquaria ( $10 \mathrm{fish}$ per aquarium), provided with constant aeration, flowing dechlorinated tap water (mean flow rate ca $15 \mathrm{l} \mathrm{h}^{-1}$ ), and held at constant temperature. Replicates were kept at 10,15 and $20^{\circ} \mathrm{C}$. The room was illuminated artificially $12 \mathrm{~h} \mathrm{~d}^{-1}$. The fish were fed a trout grower ration (Zeigler Bros, Inc., PA, USA) daily at 0.5 to $1 \%$ of their body weight. A prophylactic treatment of $2 \mathrm{ppm}$ benzalkonium chloride in the water was administered on arrival, and twice weekly, except during the inoculation week. Weekly maintenance consisted of siphoning of the detritus, and monitoring of the following water parameters: nitrite, hardness, $\mathrm{pH}$, total ammonia, temperature. The dissolved oxygen and chlorine residues were checked monthly. An acclimation period of a minimum of $15 \mathrm{~d}$ before the onset of the study was applied.
Neoplastic tissue from 5 adult brown bullheads (collected in the spring from Delta Lake, Oneida Lake, and Silver Stream reservoir, New York) anesthetized with 100 to 200 ppm of methane tricaine sulfonate (MS 222, Sandoz) was aseptically dissected and pooled for preparation of the inocula. Four representative samples of the neoplasms were fixed in $10 \%$ neutral buffered formalin for histologic confirmation of the diagnosis. The 4 groups were inoculated at 2 different sites on the lower lip/chin, by subcutaneous injection of $0.1 \mathrm{ml}$, or scarification using the inoculation needle with depot of $0.05 \mathrm{ml}$ of inoculum. Inocula consisted of: (a) cell-free, filtered tumor homogenate; (b) trypsinized neoplastic live cells; (c) brown bullhead (BB) cell line (ATCC CCL \# 59); and (d) vehicle alone (phosphate-buffered saline, PBS), and were prepared as described below

(a) Cell-free filtered tumor homogenate: Approximately $2 \mathrm{~g}$ of pooled neoplastic tissue was finely minced with scissors, homogenized with a tissue grinder, and sonically disrupted at $20 \mathrm{kHz}$ at $30 \mathrm{~W}$, during $3 \times 1$ min periods. The cellular debris was removed by centrifugation, at $1000 \times g$ for $15 \mathrm{~min}$, and the clear supernatant fluid collected and filtered through a $0.45 \mu \mathrm{m}$ cellulose acetate low affinity binding filter (Corning Glass Works, Corning, NY, USA) to remove contaminating microorganisms.

(b) Trypsinized live cells: Approximately $2 \mathrm{~g}$ of pooled neoplastic tissue was digested in $0.25 \%$ trypsin- $0.02 \%$ EDTA in PBS in a sterile glass trypsinization flask at room temperature for $1 \mathrm{~h}$. After the trypsinization time, the undigested fragments were allowed to sediment, and the collected supernatant fluid was centrifuged at $250 \times g$ for 10 min with $20 \%$ fetal bovine serum (FBS). The pellet was resuspended in sterile PBS, and the cells dispersed by vigorous pipetting. Aliquots were taken to assess total cell count and viability $(83 \%)$ by trypan blue exclusion method in a hemocytometer. Fish were injected with ca $3.5 \times 10^{6}$ live tumor cells per fish.

(c) $B B$ cell line: An established brown bullhead cell line, derived from cells of the posterior trunk tissue (ATCC CCL \# 59), was grown to confluency in Leibovitz's L15 cell culture medium, containing $15 \%$ FBS, and $1 \%$ penicillin-streptomycin-fungizone (PSF) The monolayer was trypsinized, resuspended in sterile PBS, containing $7 \%$ FBS with 500 units $\mathrm{ml}^{-1}$ penicillin $0.5 \mathrm{mg} \mathrm{ml}^{-1}$ streptomycin, $1.25 \mathrm{\mu g} \mathrm{ml}^{-1}$ amphotericin $\mathrm{B}$, and $0.1 \mathrm{mg} \mathrm{ml}^{-1}$ gentamycin. Aliquots were taken to assess total cell count and viability ( $88 \%$ ) by dye exclusion. Each fish received ca $2 \times 10^{5}$ live normal cells

Inoculated fish were observed daily for the 9 mo duration of the experiment. Dead or moribund fish were examined macroscopically, necropsied if necessary, and fixed in $10 \%$ neutral buffered formalin. Whole body transversal sections were embedded in paraffin 
cut at $6 \mu \mathrm{m}$, and stained with hematoxylin and eosin (5 cases).

Aliquots of the trypsinized live neoplastic cell inoculum were prepared for transmission electron microscopic examination. The pelleted cells were fixed in $2 \%$ glutaraldehyde in $0.1 \mathrm{M}$ cacodylate buffer $(\mathrm{pH}$ 7.3), washed in 0.1 M cacodylate buffer, and postfixed in $1 \%$ osmium tetroxide. The pellet was dehydrated through increasing concentrations of ethanol, and embedded into Epon/araldite. Thick sections ( $1 \mu \mathrm{m}$ ) were cut, and stained with toluidine blue. Thin sections were stained with uranyl acetate and lead citrate. Aliquots of the cell-free filtered tumor homogenate were prepared for examination by transmission electron microscopy by the negative stain technique. Briefly, the inoculum was centrifuged at $10000 \times \mathrm{g}$ for $30 \mathrm{~min}$. The resulting supernatant fluid was collected, centrifuged at $100000 \times g$ for 1 h (SW28 rotor, Beckman Instruments, Inc., USA), and the pellet suspended in $0.5 \mathrm{ml}$ of TNES $(10 \mathrm{mM}$ Tris- $\mathrm{HCl}, \mathrm{pH} 7.5$, $1 \mathrm{mM}$ EDTA, $100 \mathrm{mM} \mathrm{NaCl}, 5 \%$ sucrose) with $6 \mathrm{mM}$ dithiothreitol (DTT). This suspension was atomized on $300 \times 75$ formvar-coated grids with $3 \%$ phosphotungstic acid (pH 6.5) and bacitracin $\left(100 \mu \mathrm{g} \mathrm{ml}^{-1}\right)$ as a wetting agent. The samples were examined under a Zeiss TEM 902 electron microscope.

Reverse transcriptase assay. Two samples of orocutaneous neoplasms, $0.045 \mathrm{~g}$ of $-70^{\circ} \mathrm{C}$ frozen tumor tissue from 1 fish and an aliquot of the cell-free filtered tumor homogenate, which was prepared from pooled neoplastic tissue (Treatment a) and saved in TNES, were assayed for reverse transcriptase (RT) activity. The tissues were homogenized in TNES with a tissue grinder, and centrifuged at $10000 \times \mathrm{g}$ for $30 \mathrm{~min}$ at $4{ }^{\circ} \mathrm{C}$ to remove cell debris. An aliquat $(10 \mu \mathrm{l})$ was assayed in a final volume of $50 \mu \mathrm{l}$ containing $50 \mathrm{mM}$ Tris$\mathrm{HCl}, \mathrm{pH} 7.8,30 \mathrm{mM} \mathrm{KCl}, 0.6 \mathrm{mM} \mathrm{MnCl}_{2}, 2 \mathrm{mM}$ dithiothreitol (DTT), $20 \mu \mathrm{g} \mathrm{ml}^{-1}$ polyriboadenylic acid, 0.34 unit $\mathrm{ml}^{-1}$ oligo-deoxythymidylic acid 12-18 (Pharmacia LKB Biotechnology Inc., USA), $0.2 \%$ Triton X-100, and $2 \mu \mathrm{M}\left[{ }^{3} \mathrm{H}\right]$ thymidine triphosphate $\left(\left[{ }^{3} \mathrm{H}\right] \mathrm{dTTP}\right.$, specific activity $46 \mathrm{Ci} \mathrm{mM}^{-1}$; Amersham/Searle, USA). After $1 \mathrm{~h}$ incubation at room temperature, $30 \mu \mathrm{l}$ were spotted onto strips of ion exchange filter paper (DE-81, Whatman Int. Ltd, UK). The strips were washed $5 \times$ 5 min with gentle rocking at room temperature in $2 \%$ sodium phosphate, followed by $1 \mathrm{~min}$ in distilled water, and $1 \mathrm{~min}$ in $95 \%$ ethanol. The strips were then dried, and the amount of incorporated $\left[{ }^{3} \mathrm{H}\right] \mathrm{dTTP}$ was measured with a scintillation counter (LS 1801, Beckman Instruments, Inc., USA). Supernatant fluid from a culture of ovine fibroblasts infected with ovine progressive pneumonia virus (OPPV) served as a positive control, and homogenized normal brown bullhead skin and plain media were the negative controls. In order to further characterize the RT activity, experiments were repeated with $20 \mathrm{mM} \mathrm{MgCl}$ instead of $\mathrm{MnCl}_{2}$. To investigate whether the RT activity would sediment at a density characteristic of retroviruses, we layered the tumor samples in TNES on a $36 \mathrm{ml}, 15$ to $60 \%(\mathrm{w} / \mathrm{v})$ sucrose density gradient, and centrifuged at $100000 \times$ $g$ for $16 \mathrm{~h}$ (SW28 rotor). Fractions $(1.8 \mathrm{ml})$ were collected from the top of the tubes. The density of the fractions was determined by measurement of the refractive index, and RT activity was assessed in every third fraction.

Cell culture and Southern blot analysis. In an attempt to propagate in vitro an infectious agent associated with these orocutaneous neoplasms, we (1) initiated a primary culture of the neoplastic cells, and (2) inoculated a homologous cell line (BB cell line, see above) with the supernatant fluid from the primary cultures and with some of the treatment materials that we used in live fish. Aliquots of the trypsinized live neoplastic cells were used to initiate primary cultures.

The cells were suspended in Leibovitz's L15 medium, with $20 \%$ FBS, $1 \%$ PSF, and $0.1 \mathrm{mg} \mathrm{ml}^{-1}$ gentamycin, seeded in $25 \mathrm{~cm}^{2}$ cell culture flasks, and incubated at $20^{\circ} \mathrm{C}$ for $18 \mathrm{~d}$. The supernatant fluid from these primary cultures was collected after $6 \mathrm{~d}$ (see below). Monolayers of $\mathrm{BB}$ cells were grown to confluency in Leibovitz's L15 and inoculated with $1 \mathrm{ml}$ of the following treatments: (i) cell-free, filtered tumor homogenate (Treatment a); (ii) cell-free, filtered normal skin homogenate (prepared as the cell-free, filtered tumor homogenate); (iii) supernatant fluid of the primary cultures of papillomatous tissue; and (iv) vehicle alone (PBS). After $1 \mathrm{~h}$ adsorption at room temperature, the inoculated cultures were refed with Leibovitz's L15, containing $5 \% \mathrm{FBS}$ and $1 \% \mathrm{PSF}$, incubated at $20^{\circ} \mathrm{C}$ for $6 \mathrm{wk}$, during which they were observed twice weekly for cytopathic effects. Three blind passages were subsequently performed, by using the supernatant fluid of the cultures as inoculum for the new monolayers.

DNA of orocutaneous neoplasms from 5 different brown bullheads was isolated according to the following procedure. Tissues were homogenized in extraction buffer $(10 \mathrm{mM}$ Tris- $\mathrm{HCl}, \mathrm{pH} 8.0,50 \mathrm{mM}$ EDTA, $100 \mu \mathrm{g} \mathrm{ml} \mathrm{ml}^{-1}$ proteinase $\mathrm{K}$, and $1 \% \mathrm{w} / \mathrm{v}$ SDS). After overnight digestion, the lysate was extracted once with an equal volume of chloroform/isoamyl alcohol $(24 \cdot 1 \mathrm{v} / \mathrm{v})$. $\mathrm{NaCl}$ was added to achieve a final concentration of $0.1 \mathrm{M} \mathrm{NaCl}$, and the DNA was ethanol precipitated. After treatment with ribonuclease $(20 \mu \mathrm{g}$ $\left.\mathrm{ml}^{-1}\right)$, DNA was treated with phenol/chloroform $(1: 1$ $\mathrm{v} / \mathrm{v})$, extracted with chloroform/isoamyl alcohol (24:1 $v / v)$, and ethanol precipitated. The genomic DNA was dissolved in TLE $(10 \mathrm{mM}$ Tris- $\mathrm{HCl}, \mathrm{pH} 8.0,0.1 \mathrm{mM}$ EDTA). Undigested DNA was electrophoresed on a 
$1 \%$ agarose gel, and transferred to a nitrocellulose membrane according to the procedure by Sambrook et al. (1989). DNA was purified by equilibrium centrifugation in cesium chloride - ethidium bromide (CsCl-EtBr) gradients (Sambrook et al. 1989). This purified DNA was digested with Bam $\mathrm{H} 1$ restriction enzyme (New England Biolabs, Inc., USA), separated electrophoretically on a $1 \%$ agarose gel, and transferred onto a nitrocellulose membrane. The nitrocellulose blots were incubated $12 \mathrm{~h}$ at $55^{\circ} \mathrm{C}$ in prehybridization solution $[6 \times \mathrm{SSC}(15 \mathrm{mM}$ sodium citrate, $150 \mathrm{mM}$ sodium chloride, $\mathrm{pH} 7.0), 5 \times$ Denhardt's, $0.5 \%$ SDS, and $100 \mu \mathrm{g} \mathrm{ml}^{-1}$ calf thymus DNA (Sigma)]. Hybridizations were carried out for $48 \mathrm{~h}$ at $55^{\circ} \mathrm{C}$ in hybridization solution containing a ${ }^{32} \mathrm{P}$-radiolabeled, heat-denatured, mixed bovine papillomavirus and cottontail rabbit papillomavirus (BPV-CRPV) probe, or a ${ }^{32} \mathrm{P}$ radiolabeled walleye dermal sarcoma virus (WDSV) probe (specific activity = $\left.10^{8} \mathrm{cpm} \mu \mathrm{g}^{-1}\right)$. After hybridization, the filters were washed in $2 \times \mathrm{SSC}$ and $0.1 \%$ sarcosyl for 30 min at $45^{\circ} \mathrm{C}$, then in $0.2 \times \mathrm{SSC}$ and $0.1 \%$ sarcosyl at room temperature for another $30 \mathrm{~min}$. The blots were exposed for $48 \mathrm{~h}$ to $\mathrm{X}$ ray film (Kodak XAR) at $-70^{\circ} \mathrm{C}$ with intensifying screens.

\section{RESULTS}

\section{Transmissibility trial}

The trial began June 21, 1991 (study Day 1), for the groups inoculated with filtered tumor homogenate (Inoculum a) and trypsinized live cells (Inoculum b), and June 22, 1991, for the groups receiving BB cells (Inoculum c) and PBS alone (Inoculum d). It was terminated 9 mo later (study Day 275), March 21, and March 22, 1992, for groups $\mathrm{a}, \mathrm{b}$ and $\mathrm{c}$, d respectively. The orocutaneous neoplasms were not transmitted to the experimental fish under the conditions tested. At various times during the study (Days 51, 76 to 77 and 179 to 274 post-inoculation), a total of 24 brown bullheads succumbed to accidental or infectious causes unrelated to the inoculation: among the fish having received filtered tumor homogenate (Inoculum a), and maintained at $10^{\circ} \mathrm{C}, 2$ died accidentally, 4 developed mycotic der- matitis (Saprolegniasp.), and at $20^{\circ} \mathrm{C}, 3$ died of columnaris disease (Flexibacter columnaris); mycotic dermatitis was the cause of death of 5 fish at $10^{\circ} \mathrm{C}$ inoculated with live trypsinized cells (Inoculum b), 3 fish at $10^{\circ} \mathrm{C}$ inoculated with $\mathrm{BB}$ cells (Inoculum c), and 6 control fish (Inoculum d) at 10 , and 1 at $15^{\circ} \mathrm{C}$. Electron microscopic examination of the negatively-stained pellet of the cell-free tumor homogenate (Inoculum a) revealed no significant findings. Electron microscopic examination of the pelleted trypsinized live neoplastic cells (Inoculum b) confirmed the presence of abundant viable epithelial cells either detached and rounded up, or grouped in small 2 to 3 cell clusters (Fig. 1). Although Malpighian cells, the predominant component of fish epidermis, outnumbered other cell types, an occasional leukocyte or goblet cell was present in the sample. The observed Malpighian cells shared morphologic features with neoplastic epithelial cells examined within tissue sections, thereby confirming their neoplastic nature. They were characterized by an effacement of the sharp distinction between the organelle-rich perinuclear zone and the tonofilament-filled 
Table 1. Ictalurus nebulosus. RNA-dependent DNA polymerase activity (cpm) in brown bullhead tissue samples $(10 \mu \mathrm{l})$ assayed with polyriboadenylic acid and oligo-deoxythy-midylic acid. Divalent cation used was either $\mathrm{Mn}^{2+}$ or $\mathrm{Mg}^{2+} \mathrm{ND}$ not determined

\begin{tabular}{|lrrr|}
\hline \multicolumn{1}{|c}{ Cample } & & \multicolumn{1}{c|}{$\begin{array}{c}\text { Activity } \\
\mathrm{Mn}^{2+}\end{array}$} & $\mathrm{Mg}^{2+}$ \\
\hline $\begin{array}{l}\text { Fish 1, single tumor } \\
\text { Cell-free tumor homogenate, }\end{array}$ & 151220 & $\mathrm{ND}$ & 4160 \\
$\quad$ pooled tumor tissue (Treatment a) & $\mathrm{ND}$ & 34000 & $\mathrm{ND}$ \\
Negative control, normal skin & 7875 & 5865 & 2265 \\
Negative control, plain media & 7975 & 11810 & 3455 \\
Positive control, OPPV & 104360 & 115320 & 75325 \\
& & & \\
a Values are the mean of duplicate experiments & & \\
\hline
\end{tabular}

peripheral zone. Abundant small whorls of tonofilaments, which occasionally encircled groups of 10 or fewer ribosomes, coursed throughout the cytoplasm. Numerous intricate plasma membrane interdigitations and pseudopods were present at the surface. Prominent desmosomal junctions connected neighboring cells within small groups, or were engulfed within autophagosomes as a result of the trypsinization. In addition, a few variably-sized membrane-bound vacuoles developed infrequently in the peripheral cytoplasm. Other cytoplasmic components were unremarkable compared to normal Malpighian cells

\section{Reverse transcriptase assay}

The results in Table 1 show that RNA-dependent DNA polymerase, presumably RT, activity was detected both within a tumor from an individual fish and within the pooled tumor sample that served as inoculum (Treatment a) when $\mathrm{Mn}^{2+}$ was used as divalent cation. The enzymatic activity of the single tumor was higher $(151220 \mathrm{cpm})$ than that of the positive control, OPPV (104360 cpm). The negative controls, plain media and normal brown bullhead skin, had similarly low polymerase activities, approximately $1 / 20$ of that of the tumor No significant activity was observed when $\mathrm{Mg}^{2+}$ was used. After sucrose gradient centrifugation, the majority of the polymerase activity remained at the top of the gradient, at a sucrose density of 1.08 to $1.10 \mathrm{~g} \mathrm{ml}^{-1}$ (data not shown).

\section{Cell culture and Southern blot analysis}

No cytopathic effects were observed in the primary cell cultures from the papillomas, or in the BB monolayers inoculated with material from any of the 4 treat- ments. Because of the histologic appearance of these orocutaneous neoplasms, which are classified as papillomas and carcinomas (Lucké \& Schlumberger 1941, Baumann et al. 1987. Smith et al. 1989, Bowser et al. 1991, Poulet et al. in press), and because of the tentative interpretation as papillomaviruses of the viral particles detected by electron microscopy (Edwards \& Samsonoff 1977), we attempted to identify papillomavirus nucleotide sequences in the DNA from these neoplasms by using a mixed probe consisting of BPV and CRPV. Although limited, there is some sequence homology between the papillomaviruses of different mammalian species (Fenner et al. 1987). No papillomavirus has yet been identified in fish (Ferguson 1989). The mixed BPV-CRPV probe did not recognize any homologous sequences on the Southern blots of brown bullhead papilloma DNA (Fig. 2a). The relatively high level of RNA-dependent DNA polymerase activity found in the tumors prompted us to look for an exogenous retroviral agent using a recently cloned oncogenic fish retrovirus, walleye dermal sarcoma virus (WDSV) (Martineau et al. 1991, 1992). As shown in Fig. 2b, this retroviral probe did not hybridize with the DNA extracted from the brown bullhead neoplasms

\section{DISCUSSION}

Orocutaneous tumors of brown bullheads were not transmissible to healthy test brown bullheads under these experimental conditions. Previously, auto- and homotransplantation of orocutaneous neoplasms of brown bullheads within the ocular anterior chamber and between the 2 corneal layers succeeded within $2 \mathrm{wk}$; heterotransplantation in 2 remote fish species and in the leopard frog, however, was followed by rejection of the tumor material by the recipients (Lucké \& Schlumberger 1941). Unequivocal transmissibility of infectious neoplastic diseases in fish was achieved only in a few species: the northern pike Esox lucius (Mulcahy \& O'Leary 1970, Brown et al. 1975, Sonstegard 1976), common carp Cyprinus carpio (Sano et al. 1985), walleye Stizostedion vitreum (Bowser et al. 1990, Martineau et al. 1990), and salmonids (Kimura et al. 1981a, b, Sano et al. 1983, Yoshimizu et al. 1987). The Henle-Koch's postulate (Fenner et al. 1987) for establishing the etiologic relationship was fulfilled in even fewer cases (Kimura et al. 1981a, b, Sano et al. 1983, Martineau et al. 1990). The absence of transmis- 


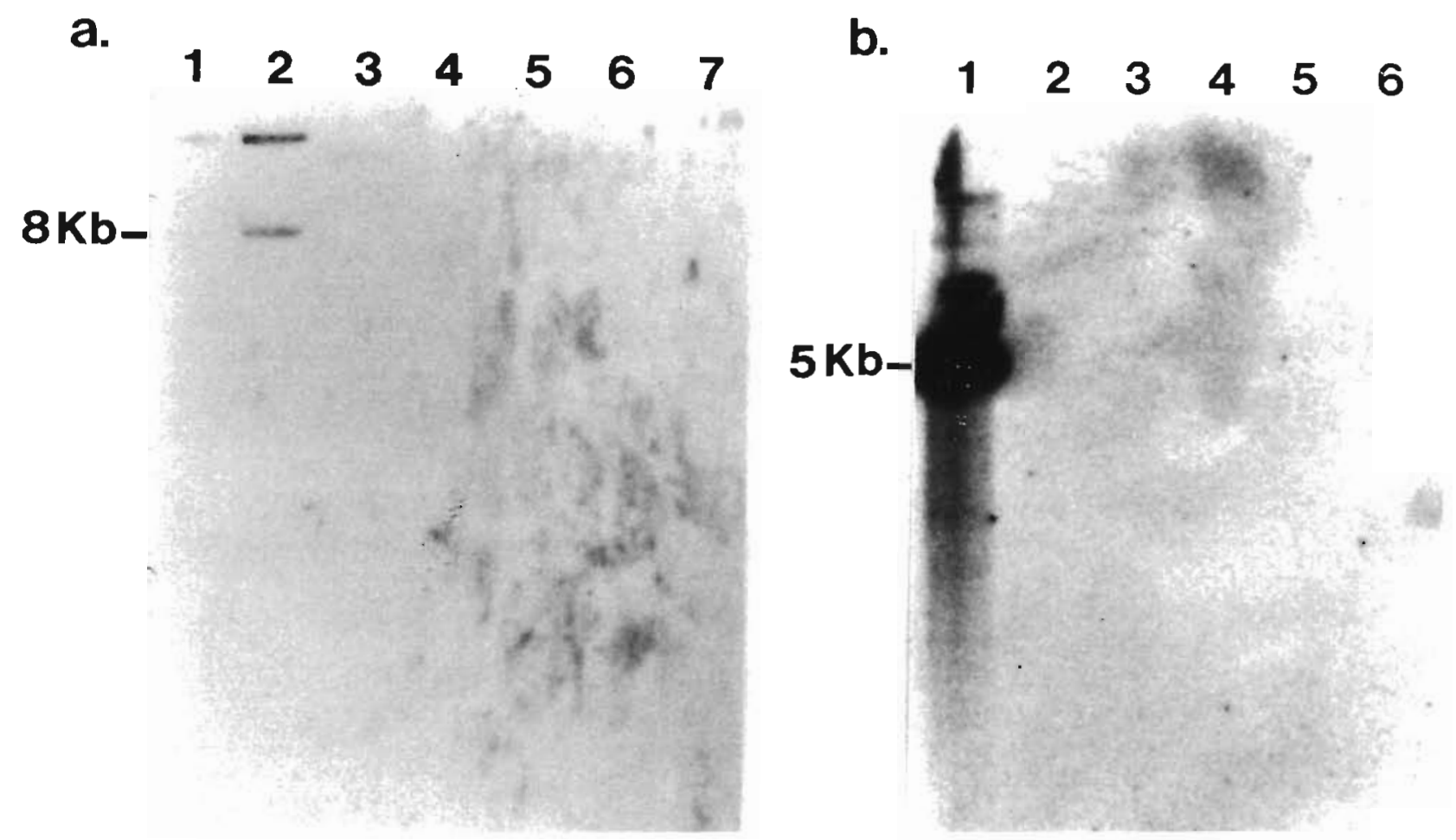

Fig. 2. Ictalurus nebulosus. Southern blots of brown bullhead orocutaneous neoplasms. The DNA of 5 fish (a: Lanes 3 to 7 ; b: Lanes 2 to 6) was digested with Bam H1 and hybridized with (a) a mixed bovine papillomavirus and cottontail rabbit papillomavirus (BPV-CRPV) probe, or (b) a walleye dermal sarcoma virus (WDSV) probe. (a) Lanes 1 \& 2: positive controls consisting of 100 and $500 \mathrm{pg}$ of plasmid DNA with the BPV insert, respectively. (b) Lane 1: positive control consisting of $20 \mathrm{ng}$ of WDSV. Molecular weights are given in kilobase $(\mathrm{Kb})$ derived from $\lambda$ Hind III standards

sibility in this case might be explained by several reasons: inoculum characteristics, age, genetic strain, physiologic (sexual hormones) and nutritional status of the test fish, water temperature, experiment duration, and absence of cocarcinogens. The trypsinized live cells (Inoculum b) were identified as neoplastic epithelial cells. No infectious particles were seen in that inoculum or in the cell-free filtered tumor homogenate (Inoculum a) by electron microscopy. All experimental fish measured approximately $10 \mathrm{~cm}$ long, but their age was not assessed. Many were sexually mature. Young animals are usually more susceptible to infections, and therefore preferred for transmissibility trials. In a number of cases in which spontaneous neoplasms developed in adult fish, oncogenicity trials were successful in fingerlings (Sonstegard 1976, Kimura et al, 1981a, b, Sano et al. 1983, Yoshimizu et al. 1987, Martineau et al. 1990). Age-related resistance to infection was also noted in 8 mo old chum salmon Oncorhynchus keta (Kimura et al. 1981b, Yoshimizu et al. 1987). But, age and physiologic status do not always seem to be of paramount importance in experimental transmission. Indeed, neoplasms could be reproduced in $1.5 \mathrm{yr}$ old common carp (Sano et al. 1985), and in adult northern pike (Mulcahy \& O'Leary 1970). Genetic strain differ- ences did not impede transmissibility in the northern pike (Mulcahy \& O'Leary 1970. Sonstegard 1976), in the common carp (Sano et al. 1985), and in salmonids (Kimura et al. 1981a, b, Sano et al. 1983, Yoshimizu et al. 1987). In this latter case, 6 different species of salmonids were successfully infected but showed variations in susceptibility to OMV: the masu salmon Oncorhynchus masou exhibited the highest tumor incidence after virus exposure, and the rainbow trout Salmo gairdneri the lowest. The influence of water temperature was assessed in walleye (Bowser et al. 1990) and northern pike (Brown et al. 1975) oncogenicity trials, and an optimal temperature for transmission was found in each case. The temperatures in our trial. represented seasonal changes, reflecting concomitant immunologic adaptations of the fish, within acceptable biological limits for the species. The experiment was terminated after 9 mo. Since the earliest occurrence of experimentally reproduced neoplasm was $18 \mathrm{~d}$ postinoculation (Brown et al. 1975), and the latest 9 mo (Yoshimizu et al. 1987), this test duration seems appropriate. A positive relationship between neoplasm induction and cocarcinogens was demonstrated in numerous cases (Brown et al. 1975, Grizzle et al. 1981, 1984, Black 1983, 1988, Fenner et al. 1987), and ex- 
plained at a molecular level by the successive activation of cellular oncogenes and/or repression of cellular cancer suppressor genes (multistep theory of carcinogenesis) (Cotran et al. 1989, Powers 1989). Our virus propagation attempts were negative, corroborating other investigators' results (Bowser et al. 1991). No homologous DNA sequences were identified by the mixed BPV-CRPV probe. Approximately $50 \%$ nucleic acid homology exists between 2 types of papillomaviruses in any given mammalian species, and some regions of the genome of papillomaviruses of different mammalian species have sufficient sequence conservation to allow cross-hybridization (Law et al. 1979, Fenner et al. 1987). In addition, our results must be further weighted against the uncertainties of sequence conservation among species as phylogenetically remote as mammals and fish. Consequently, the absence of hybridization leads us to conclude that no closely related papillomavirus species is associated with orocutaneous neoplasms in brown bullheads. WDSV is a newly recognized oncogenic retrovirus, etiologically implicated in the dermal sarcoma of another fish species, walleyes (Martineau et al. 1990, 1991). Sequence homology between retroviruses of different species has been unpredictable. Indeed, the sequence of the spleen necrosis virus isolated from a turkey is unexpectedly more related to that of murine leukemia virus than that of avian leukemia virus (Shimotohno et al. 1980, Wilhelmsen et al. 1984). As a putative RT activity was detected in neoplastic tissue of brown bullheads, DNA extracted from the orocutaneous tumors was tested for sequences related to WDSV. Negative hybridization results greatly reduce the possibility that WDSV-related sequences are within these neoplasms. However, a retroviral etiology to the brown bullheads orocutaneous neoplasms cannot be excluded on the basis of these results. RNA-dependent DNA polymerase activity, with an absolute preference for $\mathrm{Mn}^{2+}$, was detected within orocutaneous neoplasms of brown bullheads. Normal brown bullhead skin was negative. This DNA polymerase behaved as a retroviral RNAdependent DNA polymerase (RT) in that it used a ribotemplate. Preference for poly $(\mathrm{Cm})$ oligo(dG) template primer was formerly evoked as the hallmark of retroviral RNA-dependent DNA polymerase (Papas et al. 1976), but DNA polymerase activity using this template primer has since also been detected within muscle and melanoma tissues of Xiphophorus spp., complicating the biochemical distinction between viral and cellular DNA polymerases (Lüke et al. 1990). Since the discovery of RT activity in retroviruses, RNA-dependent polymerase-like activities have been associated with endogenous retroviruses and retroposons within the eukaryotic genome (Lewin 1990, Lüke et al. 1990). The difficulty therefore resides in the unequivocal at- tribution of the RT activity to an exogenous retrovirus or a cellular gene. Association of bona fide RT with exogenous retroviruses is usually based on a combination of criteria: use of a ribotemplate, physical association with the particulate fraction sedimenting at a density compatible with that of retroviruses after sucrose density gradient centrifugation and electron microscopic evidence of viral particles within the fractions with high RT activity. In northern pike lymphosarcoma and walleye dermal sarcoma, RT activity banded in sucrose gradient fractions of tumor homogenates at a density consistent with that of retroviruses $\left(1.16\right.$ to $1.18 \mathrm{~g} \mathrm{ml}^{-1}$ ) (Papas et al. 1976, Martineau et al. 1991). In addition, electron microscopic examination of these fractions demonstrated type $\mathrm{C}$ virus particles in both cases (Papas et al. 1976, Martineau et al. 1991). However, in our case, the majority of the activity was located within low density fractions ( 1.08 to $1.10 \mathrm{~g} \mathrm{ml}^{-1}$ ) after sucrose density gradient centrifugation. This could be attributed to the degradation of viral particles during sample collection and storage. Conversely, the detected RNAdependent DNA polymerase activity might be cellular in origin. In the Xiphophorus melanoma system, DNA polymerases, biochemically similar to retroviral RT and isolated from muscle and melanoma, were associated with microsome-like structures banding at $1.13 \mathrm{~g} \mathrm{ml}^{-1}$ after sucrose density gradient centrifugation (Lüke et al. 1990). The RNA-dependent DNA polymerase activity detected in the brown bullhead neoplasms awaits further characterization in order to determine its exogenous or endogenous origin.

In conclusion, orocutaneous neoplasms of brown bullheads are not transmissible to healthy fish under these experimental conditions. No evidence of a viral etiology was demonstrated. However, RNA-dependent DNA polymerase, presumably RT, activity was present within the neoplasms, but its retroviral or cellular origin is undetermined and warrants further study. The etiology of orocutaneous neoplasms of brown bullheads remains unresolved, and is probably integrated into the broad scheme of multistep carcinogenesis.

Acknowledgements. We thank Drs L. Chow and T Broker for providing the BPV and CRPV plasmids. F.M.P. was supported by a graduate assistantship from New York State College of Veterinary Medicine, Cornell University. This project was funded in part by the New York State 'Return a Gift to Wildlife' Fund. The manager and staff of the New York State Department of Environmental Conservation are gratefully acknowledged for their assistance in the fish collection

\section{LITERATURE CITED}

Ahne, W., Kurstak, E. (eds.) (1989). Viruses of lower vertebrates. Springer-Verlag, Berlin

Anders, K. (1989). A Herpesvirus associated with an epizootic 
epidermal papillomatosis in European smelt (Osmerus eperlanus). In: Ahne, W., Kurstak, E. (eds.) Viruses of lower vertebrates. Springer-Verlag, Berlin, p. 184-197

Baumann, P. C., Smith, W. D., Parland, W. K. (1987). Tumor frequencies and contaminant concentrations in brown bullheads from an industrialized river and a recreational lake. Trans. Am. Fish. Soc. 116: 79-86

Black, J J (1983). Field and laboratory studies of environmental carcinogenesis in Niagara river fish. J. Great Lakes Res. 9: 326-334

Black, J. J (1988). Fish tumors as known field effects of contaminants. In: Schmidtke, M. (ed.) Toxic contamination in large lakes. Lewis, Chelsea, MI, p. 55-81

Bowser, P. R., Martineau, D., Wooster, G. A. (1990). Effects of water temperature on experimental transmission of dermal sarcoma in fingerling walleyes. J. Aquat. Anim. Hilth 2: $157-161$

Bowser, P. R., Wolfe, M. J., Reimer, J., Shane, B. S. (1991). Epizootic papillomas in brown bullheads Ictalurus nebulosus from Silver Stream reservoir, New York. Dis. aquat. Org. 11:117-127

Brown, E. R., Dolowy, W. C., Sinclair, T., Keith, L., Greenberg, S., Hazdra, J. J., Beamer, P., Callaghan, O. (1975). Enhancement of lymphosarcoma transmission in Esox lucius and its epidemiologic relationship to pollution. Comp. Leukemia Res. 43: 245-251

Cotran, R. S., Kumar, V., Robbins, S. L. (1989). Pathologic basis of disease, 4 th edn. Harcourt Brace Jovanovich, Inc., Philadelphia

Edwards, M. R., Samsonoff, W. A. (1977). Electron microscopic observations on virus-like particles of a catfish papilloma. Proc. Ann. Meet. Electron Microsc. Soc. Amer. 35 $394-395$

Fenner, F., Bachmann, P. A., Gibbs, E. P. J., Murphy, F. A., Studdert, M. J., White, D. O. (1987). Veterinary virology. Academic Press, Inc, San Diego

Ferguson, H.W. (1989). Systemic pathology of fish. A text and atlas of comparative responses in diseases of teleosts. Iowa State University Press, Ames

Grizzle, J. M., Melius, P., Strength, D. R. (1984). Papillomas on fish exposed to chlorinated wastewater effluent. J natn. Cancer Inst. 73: 1133-1142

Grizzle, J. M., Schwedler, T. E., Scott, A. L. (1981). Papillomas of black bullheads, Ictalurus melas (Rafinesque), living in a chlorinated sewage pond. J. Fish Dis. 4: 345-351

Harshbarger, J. C., Clark, J. B. (1990). Epizootiology of neoplasms in bony fish of North America. Sci. total Environ 94: $1-32$

Kimura, T., Yoshimizu, M., Tanaka, M. (1981a). Studies on a new virus (OMV) from Oncorhynchus masou - II. Oncogenic nature. Fish. Pathol. 15: 149-153

Kimura, T., Yoshimizu, M., Tanaka, M., Sannohe, H. (1981b). Studies on a new virus (OMV) from Oncorhynchus masou - I. Characteristics and pathogenicity. Fish. Pathol. 15: 143-147

Law, M.-F, Lancaster, W. D., Howley, P. M. (1979). Conserved polynucleotide sequences among the genomes of papillomaviruses. J. Virol. 32: 199-207

Lewin, B. (1990). Genes IV, 4th edn. Oxford University Press and Cell Press, New York

Lucké, B., Schlumberger, H. (1941). Transplantable epithelio- mas of the lip and mouth of catfish. I. Pathology Transplantation to anterior chamber of eye and into cornea. J. exp. Med. 74:397-416

Lüke, W., Petry, H., Hoefer, K., Anders, A., Anders, F (1990). Detection of RNA-dependent DNA polymerase activity in the Xiphophorus melanoma system. Eur. J. Biochem. 188 $301-308$

Martineau, D., Bowser, P. R., Renshaw, R. R., Casey, J. W. (1992). Molecular characterization of a unique Retrovirus associated with a fish tumor. J. Virol. 66: 596-599

Martineau, D., Bowser, P. R., Wooster, G. A., Armstrong, L. D. (1990). Experimental transmission of a dermal sarcoma in fingerling walleyes (Stizostedion vitreum vitreum). Vet. Pathol. 27: 230-234

Martineau, D., Renshaw, R. R., Williams, J. R., Casey, J. W., Bowser, P. R. (1991). A large unintegrated retrovirus DNA species present in a dermal tumor of walleye Stizostedion vitreum. Dis. aquat. Org. 10:153-158

Moulton, J. E. (1990). Tumors in domestic animals, 3rd edn. University of California Press, Berkeley

Mulcahy, M. F., O'Leary, A. (1970). Cell-free transmission of lymphosarcoma in the northern pike Esox lucius L (Pisces; Esocidae). Experientia 26: 891

Papas, T. S., Dahlberg, J. E., Sonstegard, R. A. (1976). Type C virus in lymphosarcoma in northern pike (Esox lucius). Nature 261: 506-508

Poulet, F. M., Wolfe, M. J., Spitsbergen, J. M. (in press). Description of the naturally occurring orocutaneous papillomas and carcinomas of brown bullheads (Ictalurus nebulosus) in New York State. Vet. Pathol.

Powers, D. A. (1989). Fish as model systems. Science 246 : $352-357$

Sambrook, J., Fritsch, E. F., Maniatis, T (1989). Molecular cloning: a laboratory manual, 2nd edn. Cold Spring Harbor Laboratory Press, New York

Sano, T., Fukuda, H., Furukawa, M. (1985). Herpesvirus cyprini: biological and oncogenic properties. Fish. Pathol. 20: $381-388$

Sano, T., Fukuda, H., Okamoto, N, Kaneko, F. (1983). Yamame Tumor Virus: lethality and oncogenicity. Bull. Jap. Soc. Sci. Fish. 49: 1159-1163

Shimotohno, K., Mizutani, S., Temin, H. M. (1980). Sequence of retrovirus provirus resembles that of bacterial transposable elements. Nature 285: 550-554

Smith, I. R., Ferguson, H. W., Hayes, M. A. (1989). Histopathology and prevalence of epidermal papillomas epidemic in brown bullhead. Ictalurus nebulosus (Lesueur), and white sucker, Catostomus commersoni (Lacépède), populations from Ontario, Canada. J Fish. Dis. 12: $373-388$

Sonstegard, R. A. (1976). Studies of the etiology and epizootiology of lymphosarcoma in Esox (Esox lucius L. and Esox masquinongy). Prog. exp. Tumor Res. 20: 141-155

Wilhelmsen, K. C., Eggleton, K., Temin, H. M. (1984). Nucleic acid sequences of the oncogene $\mathrm{v}$-rel in reticuloendotheliosis virus strain $T$ and its cellular homolog, the protooncogene c-rel. J Virol. 52: 172-182

Yoshimizu, M., Tanaka, M., Kimura, T. (1987). Oncorhynchus masou virus (OMV): incidence of tumor development among experimentally infected representative salmonid species. Fish Pathol. 22: 7-10 